\title{
"The impact of stock market development on economic growth: A GMM approach"
}

\begin{tabular}{|c|c|c|}
\hline AUTHORS & $\begin{array}{l}\text { Toan Ngoc Bui (i) } \\
\text { Thu-Trang Thi Doan (iD) }\end{array}$ & \\
\hline ARTICLE INFO & $\begin{array}{l}\text { Toan Ngoc Bui and Thu-Trang } \\
\text { development on economic grow } \\
\text { and Financial Innovations, } 18(3\end{array}$ & $\begin{array}{l}\text { he impact of stock market } \\
\text { h. Investment Management } \\
11 \text { /imfi.18(3).2021.07 }\end{array}$ \\
\hline DOI & http://dx.doi.org/10.21511/imfi.18 & \\
\hline RELEASED ON & Friday, 06 August 2021 & \\
\hline RECEIVED ON & Saturday, 26 June 2021 & \\
\hline ACCEPTED ON & Monday, 02 August 2021 & \\
\hline LICENSE & $\begin{array}{l}(c) E_{\text {EY }} \\
\text { This work is licensed under a C } \\
\text { License }\end{array}$ & Attribution 4.0 International \\
\hline JOURNAL & "Investment Management and F & \\
\hline ISSN PRINT & $1810-4967$ & \\
\hline ISSN ONLINE & $1812-9358$ & \\
\hline PUBLISHER & LLC "Consulting Publishing Cor & erspectives" \\
\hline FOUNDER & LLC "Consulting Publishing Cor & erspectives" \\
\hline$\sigma^{0}$ & $B$ & $\begin{array}{l}\text { ニこ: } \\
\text { ニここ }\end{array}$ \\
\hline NUMBER OF REFERENCES & NUMBER OF FIGURES & NUMBER OF TABLES \\
\hline 42 & 1 & 6 \\
\hline
\end{tabular}

(c) The author(s) 2021. This publication is an open access article. 


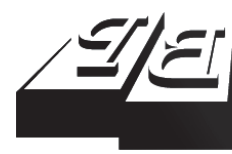

\section{BUSINESS PERSPECTIVES}

(O)

LLC "CPC "Business Perspectives" Hryhorii Skovoroda lane, 10, Sumy, 40022, Ukraine www.businessperspectives.org
Received on: $26^{\text {th }}$ of June, 2021 Accepted on: $2^{\text {nd }}$ of August, 2021 Published on: $6^{\text {th }}$ of August, 2021

(c) Toan Ngoc Bui, Thu-Trang Thi Doan 2021

Toan Ngoc Bui, Lecturer, Faculty of Finance and Banking, Industrial University of Ho Chi Minh City (IUH) Vietnam. (Corresponding author)

Thu-Trang Thi Doan, Lecturer, Faculty of Finance and Banking, Industrial University of Ho Chi Minh City (IUH), Vietnam.

\section{THE IMPACT OF STOCK MARKET DEVELOPMENT ON ECONOMIC GROWTH: A GMM APPROACH}

\begin{abstract}
This study investigated the impact of stock market development (SMD) on economic growth (EG) among emerging markets and developing economies (EMDEs) in Asia. The data sample includes eight Asian EMDEs (China, Indonesia, India, Sri Lanka, Malaysia, the Philippines, Thailand, and Vietnam) from 2008 to 2019. These countries share several similarities, so this ensures reliability of the results. Regarding the analysis, the generalized method of moments (GMM) is used for the estimation. The results show that SMD exerts a positive impact on EG. This finding confirms the importance of SMD in improving efficient capital accumulation and allocation, and also allows investors to reduce risks and increase liquidity, which will boost EG. Further, the significant influence of domestic credit (DC), control of corruption (CC), and inflation (INF) on EG is also highlighted. These findings are valuable empirical evidence that greatly contributes to reinforcing the suitability of classical economic growth theories, especially the theory of endogenous growth. They are also essential to EMDEs in Asia. Accordingly, the EMDEs should develop effective policies to improve the stock market's scale, which contributes substantially to the development of EG. Moreover, these economies need to pursue many appropriate policies in sync, such as stimulating SMD, improving governance effectiveness and implementing effective macroeconomic policies.
\end{abstract}

\section{Keywords}

economic growth, EMDEs, GMM, market capitalization, stock market development

JEL Classification F43, G15, G23

\section{INTRODUCTION}

The impact of SMD on EG is an interesting topic that has been mentioned in some empirical studies. Generally, SMD plays a crucial role in promoting EG. Therefore, many countries have developed policies for boosting SMD to promote EG (King \& Levine, 1993a, 1993b; Nguyen \& Bui, 2019; Pradhan et al., 2014; Reinhart \& Tokatlidis, 2003). To formulate and implement these policies effectively, it is necessary to create reliable empirical evidence on the influence of SMD on EG. However, theories of this impact are relatively vague. It is because most of them have only mentioned the impact of financial development - which is mainly the banking sector - on EG. Meanwhile, the credit market is unable to operate well without the stock market (Cho, 1986). This topic is still not commonly considered in empirical studies. Further, there exist contradictory views in the current studies. Besides, this has received little attention in empirical studies in Asia, especially among the EMDEs. The term EMDEs is used by the International Monetary Fund (IMF) to refer to the countries that are experiencing developing market economies and in transition to developed countries (Mody, 2004). Their similar features are their low or middle income but rapid economic growth, and more especially the adoption of a free-market system for boosting EG (Hoskisson et al., 2000). On the 
other hand, their stock markets are quite nascent and limited. However, they are active in promoting SMD for the improvement of EG. Consequently, it is really important to reveal empirical evidence on the impact of SMD on EG in EMDEs.

\section{LITERATURE REVIEW}

SMD is one of the most vital indicators influencing EG (Beck \& Levine, 2004; Naceur \& Ghazouani, 2007). Its effect on EG can be explained by several classical theories such as the classical growth theory (Ricardo, 1817; Smith, 1776), Keynes' growth theory (Keynes, 1936), the neoclassical growth theory (Solow, 1956; Swan, 1956), and the endogenous growth theory (Barro, 1991; Lucas, 1988; Mankiw et al., 1992). Apparently, all of them affirmed the importance of capital to EG. Moreover, the neoclassical growth theory mentioned the role of labor force and technology. Besides, both Keynes' growth theory and the endogenous growth theory assumed that EG is significantly affected by government policies. In general, the endogenous growth model is superior to the previous ones. However, it has the same limitation as others in that it does not consider the role of the stock market (Pan \& Mishra, 2017). This limitation has been found in several empirical studies. Specifically, Schumpeter (1911) was the first to investigate the effect of financial development on EG. Then this impact was examined by McKinnon (1973), Shaw (1973), Rousseau and Wachtel (2000), Xu (2000), Rousseau and Vuthipadadorn (2005), and Botev et al. (2019). From another perspective, Olwenyand and Kimani (2011) only analyzed the influence of the financial market on EG in Kenya. Generally, most of them reported the positive effect of financial development on EG. Nevertheless, there is still a big limitation in analyzing financial development only through the banking sector and not through the stock market. Meanwhile, through SMD, capital accumulation and allocation can be performed efficiently, thereby affecting EG. Even without the stock market, the credit market cannot operate well (Cho, 1986). Consequently, the impact of SMD on EG has received a lot of attention in a large number of empirical studies.

SMD can have a positive impact on EG. This is what has been frequently highlighted in the previous studies. Accordingly, SMD enables effective capital accumulation and allocation, which in turn promotes EG. More than that, SMD allows investors to reduce their investment risks and raise liquidity (Ngare et al., 2014). It can be said that SMD is a keystone in economic activities. The positive influence of SMD on EG has been revealed by Atje and Jovanovich (1993), Korajczyk (1996), Levine and Zervos (1998), Garrestsen et al. (2004), Nieuwerburgh et al. (2006), Colombage (2009), Enisan and Olufisayo (2009), Tsouma (2009), Cooray (2010), Kolapo and Adaramola (2012), and Pradhan et al. (2014). Broadly speaking, a majority of earlier studies have concluded that SMD is positively related to EG. However, it was also stated that this impact depends on different factors. Indeed, Garrestsen et al. (2004) recognized the positive effect of SMD on economic activities, which was developed by Levine and Zervos (1998), could disappear when other legal and social factors were controlled. Furthermore, the result could vary according to dataset, variables, time, and analyses (Pan \& Mishra, 2017). In Asia, few studies have considered the impact of SMD on EG. In particular, Estrada et al. (2010) and Setiawan et al. (2020) found a positive effect of SMD on EG in Asian countries. These studies agreed on the major role of SMD in boosting EG, especially in the post-financial crisis era. Also, policymakers need to give priority to appropriate policies to improve the stock market's scale, thereby stimulating EG. Recently, Setiawan et al. (2020) also announced a similar finding by analyzing the data of Association of Southeast Asian Nations (ASEAN) countries.

A limited number of studies, namely those of Demirguoc-Kunt and Levine (1996) and Pan and Mishra (2017), have reported a negative impact of SMD on EG. Specifically, SMD stimulates investment in the stock market, which leads to a decrease in savings rate, since investors have a consumption tendency rather than earning one, thereby reducing investment in the economy, as well as capital accumulation in the future (Demirguoc-Kunt \& Levine, 1996). On the other hand, SMD can increase financial instability, 
which will reduce EG. Further, the excessive and badly controlled capital from the stock market to the economy may hinder EG.

Broadly speaking, most of the earlier studies only investigated the impact of financial development, which is focused on the banking sector on EG. The impact of SMD on EG is still a theoretically vague topic that is not frequently empirically studied. There are also contradictory opinions on this matter. In specific, a majority of these studies reported a positive effect of SMD on EG. However, some researchers argue that SMD can negatively affect EG. On the other hand, only a limited number of empirical studies have examined the impact of SMD on EG in Asian countries, more especially in EMDEs. In modern literature, this can be seen as a big limitation. Therefore, it can be said that the impact of SMD on EG in Asian EMDEs is an interesting research topic and there are still many gaps that need to be explored.

For EMDEs in Asia, SMD is improving significantly, this makes an important contribution to the promotion of the efficient accumulation and allocation of capital, which in turn can promote EG. Based on this, the research hypothesis proposed in this study is as follows:

$H_{0}: S M D$ has a positive impact on $E G$ in Asian EMDEs.

\section{ECONOMETRIC METHODOLOGY AND DATA}

This study analyzed the impact of SMD on EG in Asian EMDEs using the following equation:

$$
E G_{i t}=\alpha+\lambda S M D_{i t}+\beta C V_{i t}+\varepsilon_{i t}
$$

where $E G$ is economic growth. $E G$ is measured by the logarithm of GDP per capita that was used by Cooray (2010) and Botev et al. (2019). SMD is the stock market development. This measure was suggested by Cooray (2010), Estrada et al. (2010), Ngare et al. (2014), Pradhan et al. (2014), Pan and Mishra (2017), Botev et al. (2019), and Setiawan et al. (2020).
To ensure stability, this study includes some control variables (CV), including domestic credit (DC), labor force (LF), control of corruption (CC), and inflation (INF). In specific, DC proxies financial development through the banking sector (Botev et al., 2019; Pradhan et al., 2014), and LF indicates the labor force (Botev et al., 2019; Cooray, 2010). $\mathrm{CC}$ is the control of corruption in each country (Ngare et al., 2014) that demonstrates a high level of corruption with its low value, and vice versa. INF refers to the macroeconomy previously used by Ngare et al. (2014), Pradhan et al. (2014), and Botev et al. (2019).

Table 1. Summary of the variables

\begin{tabular}{|c|c|c|}
\hline \multicolumn{2}{|l|}{ Variable } & Definition \\
\hline $\begin{array}{l}\text { Economic } \\
\text { growth }\end{array}$ & EG & Logarithm of GDP per capita \\
\hline $\begin{array}{l}\text { Stock market } \\
\text { development }\end{array}$ & SMD & Market capitalization (\% of GDP) \\
\hline Domestic credit & DC & $\begin{array}{l}\text { Domestic credit to the private sector } \\
\qquad(\% \text { of GDP) }\end{array}$ \\
\hline Labor force & LF & Growth of labor force (annual \%) \\
\hline $\begin{array}{l}\text { Control of } \\
\text { corruption }\end{array}$ & $\mathrm{CC}$ & $\begin{array}{c}\text { Corruption control index, which shows } \\
\text { the effectiveness of government } \\
\text { control }\end{array}$ \\
\hline Inflation & INF & Consumer prices (annual \%) \\
\hline
\end{tabular}

This study uses the GMM suggested by Arellano and Bond (1991) to estimate model (1). This method, which was also employed by Cooray (2010) and Botev et al. (2019), allows control of endogeneity issues as well as model robustness. Its superiority allows resolving limitations of other traditional methods.

In this study, the data sample collected from Asian EMDEs consists of countries with similar characteristics, such as their low or middle income and rapid economic growth (Hoskisson et al., 2000). According to IMF, EMDEs in Asia include 30 countries. Nevertheless, this study provided a full dataset for only eight Asian EMDEs over the 20082019 period, including China, Indonesia, India, Sri Lanka, Malaysia, the Philippines, Thailand, and Vietnam. During data collection, the data sample ensures that the panel is strongly balanced to improve reliability.

CC data are gathered from the Worldwide Governance Indicator (WGI), while data for the rest variables are collected from the official World Bank Database websites. 


\section{EMPIRICAL ANALYSIS}

Table 2 presents preliminary statistics for the eight EMDEs in Asia from 2008 to 2019.

Table 2. Summary statistics

\begin{tabular}{|c|c|c|c|c|}
\hline Variable & Mean & Std. Dev & Min & Max \\
\hline \multicolumn{5}{|c|}{ Panel A: full sample } \\
\hline$\overline{E G}$ & 8.205 & 0.650 & 6.906 & 9.343 \\
\hline SMD & 65.231 & 35.651 & 10.527 & 160.260 \\
\hline DC & 82.391 & 45.229 & 25.516 & 165.390 \\
\hline $\mathrm{LF}$ & 1.173 & 1.383 & -2.585 & 4.559 \\
\hline $\mathrm{CC}$ & 42.233 & 9.893 & 21.053 & 67.299 \\
\hline INF & 4.631 & 4.110 & -0.900 & 23.115 \\
\hline \multicolumn{5}{|c|}{ Panel B: China } \\
\hline$\overline{E G}$ & 8.796 & 0.362 & 8.151 & 9.232 \\
\hline SMD & 56.406 & 12.939 & 38.717 & 74.022 \\
\hline DC & 138.874 & 18.825 & 102.004 & 165.390 \\
\hline $\mathrm{LF}$ & 0.135 & 0.196 & -0.255 & 0.383 \\
\hline CC & 42.308 & 5.174 & 33.333 & 49.038 \\
\hline INF & 2.591 & 1.777 & -0.728 & 5.925 \\
\hline \multicolumn{5}{|c|}{ Panel C: Indonesia } \\
\hline$E G$ & 8.113 & 0.205 & 7.681 & 8.327 \\
\hline SMD & 42.841 & 8.293 & 19.356 & 51.268 \\
\hline DC & 34.348 & 4.935 & 27.253 & 39.402 \\
\hline $\mathrm{LF}$ & 1.853 & 0.662 & 0.664 & 2.617 \\
\hline CC & 34.668 & 8.464 & 21.053 & 48.077 \\
\hline INF & 5.176 & 2.011 & 3.031 & 10.227 \\
\hline \multicolumn{5}{|c|}{ Panel D: India } \\
\hline$E G$ & 7.334 & 0.228 & 6.906 & 7.650 \\
\hline SMD & 74.323 & 14.382 & 53.983 & 97.387 \\
\hline DC & 50.477 & 1.402 & 48.124 & 52.386 \\
\hline $\mathrm{LF}$ & 0.707 & 0.336 & 0.173 & 1.458 \\
\hline CC & 42.566 & 5.091 & 35.545 & 49.519 \\
\hline INF & 7.706 & 2.878 & 2.491 & 11.989 \\
\hline \multicolumn{5}{|c|}{ Panel E: Sri Lanka } \\
\hline$E G$ & 8.103 & 0.246 & 7.619 & 8.314 \\
\hline SMD & 23.711 & 6.429 & 10.527 & 35.123 \\
\hline DC & 37.958 & 8.774 & 25.516 & 49.903 \\
\hline $\mathrm{LF}$ & 0.416 & 1.765 & -2.585 & 3.581 \\
\hline CC & 45.289 & 3.816 & 41.148 & 51.659 \\
\hline INF & 6.474 & 5.418 & 2.135 & 22.564 \\
\hline \multicolumn{5}{|c|}{ Panel F: Malaysia } \\
\hline$E G$ & 9.212 & 0.136 & 8.895 & 9.343 \\
\hline SMD & 130.670 & 22.146 & 81.988 & 160.260 \\
\hline DC & 115.166 & 7.907 & 96.748 & 123.104 \\
\hline LF & 2.719 & 1.076 & 1.651 & 4.559 \\
\hline CC & 61.566 & 3.677 & 56.796 & 67.299 \\
\hline INF & 2.279 & 1.428 & 0.583 & 5.441 \\
\hline \multicolumn{5}{|c|}{ Panel G: the Philippines } \\
\hline$E G$ & 7.903 & 0.196 & 7.553 & 8.156 \\
\hline SMD & 72.078 & 17.200 & 28.745 & 88.407 \\
\hline DC & 36.861 & 7.779 & 27.876 & 47.977 \\
\hline LF & 2.045 & 1.494 & -2.069 & 3.429 \\
\hline CC & 33.397 & 6.908 & 23.333 & 43.602 \\
\hline INF & 3.556 & 1.982 & 0.674 & 8.260 \\
\hline \multicolumn{5}{|c|}{ Panel H: Thailand } \\
\hline$E G$ & 8.666 & 0.182 & 8.346 & 8.963 \\
\hline SMD & 87.962 & 23.031 & 35.393 & 120.272 \\
\hline DC & 134.433 & 15.568 & 105.760 & 149.373 \\
\hline $\mathrm{LF}$ & 0.082 & 1.293 & -2.104 & 2.875 \\
\hline $\mathrm{CC}$ & 42.640 & 3.398 & 37.019 & 47.393 \\
\hline INF & 1.708 & 1.931 & -0.900 & 5.468 \\
\hline \multicolumn{5}{|c|}{ Panel I: Vietnam } \\
\hline$E G$ & 7.512 & 0.290 & 7.047 & 7.907 \\
\hline SMD & 33.855 & 14.580 & 12.474 & 57.199 \\
\hline DC & 111.014 & 17.306 & 82.873 & 137.912 \\
\hline $\mathrm{LF}$ & 1.430 & 0.631 & 0.458 & 2.478 \\
\hline CC & 35.431 & 4.155 & 28.155 & 41.827 \\
\hline INF & 7.554 & 6.819 & 0.631 & 23.115 \\
\hline
\end{tabular}

Figure 1 presents GDP per capita and SMD of Asian EMDEs in 2019. Accordingly, stock market capitalization to GDP in Malaysia and Thailand is quite high while it is limited in Sri Lanka.

Table 3. Correlation matrix

\begin{tabular}{|c|c|c|c|c|c|c|}
\hline Variable & EG & SMD & DC & LF & CC & INF \\
\hline EG & 1.000 & & & & & \\
\hline \multirow{2}{*}{ SMD } & $0.545^{* * *}$ & 1.000 & & & & \\
\hline & {$[0.000]$} & & & & & \\
\hline \multirow{2}{*}{ DC } & $0.587^{* * *}$ & $0.386^{* * *}$ & 1.000 & & & \\
\hline & [0.000] & {$[0.000]$} & & & & \\
\hline \multirow{2}{*}{ LF } & 0.025 & $0.203^{* *}$ & $-0.210^{* *}$ & 1.000 & & \\
\hline & {$[0.806]$} & {$[0.048]$} & {$[0.040]$} & & & \\
\hline \multirow{2}{*}{$\mathrm{CC}$} & $0.620^{* * *}$ & $0.567^{* * *}$ & $0.341^{* * *}$ & 0.110 & 1.000 & \\
\hline & {$[0.000]$} & [0.000] & {$[0.001]$} & {$[0.285]$} & & \\
\hline \multirow{2}{*}{ INF } & $-0.601^{* * *}$ & $-0.447^{* * *}$ & $-0.373^{* * *}$ & 0.068 & $-0.273^{* * *}$ & 1.000 \\
\hline & {$[0.000]$} & {$[0.000]$} & {$[0.000]$} & {$[0.512]$} & {$[0.007]$} & \\
\hline
\end{tabular}

Note: $* * *$ - significant at $1 \%, * *$ - significant at $5 \%$.

The results indicate that EG is negatively related to INF. Meanwhile, the other variables are positively associated with EG (Table 3). In addition, there is no serious multicollinearity in the model due to a low correlation between independent and control variables.

Table 4. Estimated results

\begin{tabular}{|c|c|c|c|}
\hline Variable & Pooled OLS & FEM & REM \\
\hline \multirow{2}{*}{$\alpha$} & $6.949^{* * *}$ & $6.754^{* * *}$ & $6.899^{* * *}$ \\
\hline & {$[0.000]$} & {$[0.000]$} & {$[0.000]$} \\
\hline \multirow{2}{*}{ SMD } & 0.001 & 0.001 & 0.001 \\
\hline & [0.813] & {$[0.628]$} & [0.433] \\
\hline \multirow{2}{*}{$\mathrm{DC}$} & $0.005^{* * *}$ & $0.013^{* * *}$ & $0.008^{* * *}$ \\
\hline & {$[0.000]$} & {$[0.000]$} & [0.000] \\
\hline \multirow{2}{*}{ LF } & 0.034 & 0.012 & 0.012 \\
\hline & {$[0.282]$} & {$[0.411]$} & {$[0.507]$} \\
\hline \multirow{2}{*}{$\mathrm{CC}$} & $0.026^{* * *}$ & $0.012^{* * *}$ & $0.015^{* * *}$ \\
\hline & {$[0.000]$} & {$[0.000]$} & {$[0.000]$} \\
\hline \multirow{2}{*}{ INF } & $-0.059^{* * *}$ & $-0.014^{* * *}$ & $-0.019^{* * *}$ \\
\hline & {$[0.000]$} & {$[0.006]$} & {$[0.001]$} \\
\hline$R$-squared & $66.65 \%$ & $67.41 \%$ & $64.08 \%$ \\
\hline \multirow{2}{*}{$\begin{array}{l}\text { Significance } \\
\text { level }\end{array}$} & $35.98^{* * *}$ & $34.34^{* * *}$ & $142.04^{* * *}$ \\
\hline & [0.000] & {$[0.000]$} & {$[0.000]$} \\
\hline \multirow{2}{*}{$F$ test } & & $84.57^{* * *}$ & \\
\hline & & [0.000] & \\
\hline \multirow{2}{*}{$\begin{array}{l}\text { Hausman } \\
\text { test }\end{array}$} & & $14.89^{* *}$ & \\
\hline & & [0.011] & \\
\hline
\end{tabular}

Note: $* *$ - significant at $5 \%, * * *-$ significant at $1 \%$.

As can be seen, the FEM is superior to the others when the $\mathrm{F}(\mathrm{F}(7,83)=84.57)$ and Hausman $($ chi2 $(5)=14.89)$ tests are statistically significant (Table 4). 


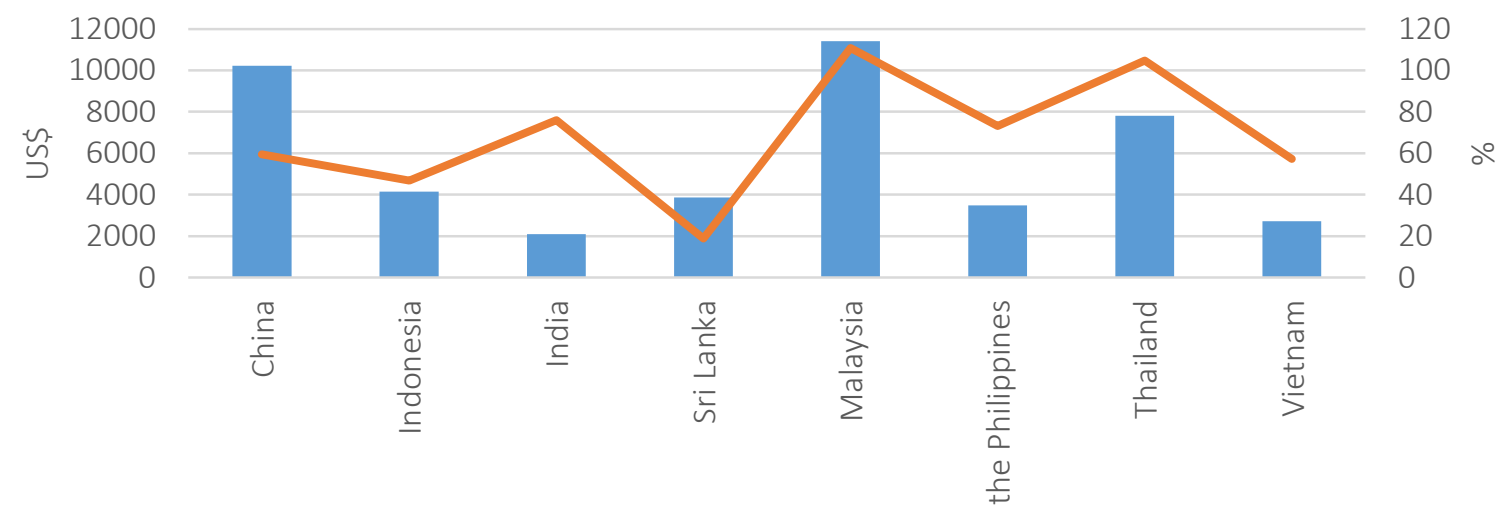

GDP per capita (current US\$)

Market capitalization of listed domestic companies (\% of GDP)

Figure 1. GDP per capita and SMD of Asian EMDEs in 2019

Table 5. Model testing results

\begin{tabular}{|c|c|c|c|c|}
\hline \multicolumn{3}{|c|}{ Multicollinearity test } & \multirow{2}{*}{$\begin{array}{l}\text { Modified } \\
\text { Wald test }\end{array}$} & \multirow{2}{*}{$\begin{array}{c}\text { Wooldridge } \\
\text { test }\end{array}$} \\
\hline Variable & VIF & Tolerance & & \\
\hline SMD & 1.89 & 0.530 & $46.57^{* * *}$ & $81.536^{* * *}$ \\
\hline DC & 1.40 & 0.714 & \multirow{5}{*}[0.000]{} & \multirow{5}{*}[0.000]{} \\
\hline LF & 1.18 & 0.848 & & \\
\hline CC & 1.52 & 0.660 & & \\
\hline INF & 1.34 & 0.744 & & \\
\hline \multicolumn{3}{|c|}{ Mean VIF $=1.47$} & & \\
\hline
\end{tabular}

Note: $* * *$ - significant at $1 \%$.

As can be seen from Table 5, the model is free of multicollinearity issues. However, autocorrelation and heteroscedasticity issues are statistically significant. As a result, the GMM suggested by Arellano and Bond (1991) was used to estimate the most reliable results.

Table 6. Results using the GMM

\begin{tabular}{l|c}
\hline \multicolumn{1}{c|}{ Variable } & EG \\
\hline$\alpha$ & $6.975^{* * *}$ \\
\hdashline SMD & {$[0.000]$} \\
\hdashline DC & $0.002^{* *}$ \\
\hdashline LF & {$[0.045]$} \\
\hdashline CC & $0.005^{* * *}$ \\
\hdashline INF & {$[0.000]$} \\
\hdashline$\ldots \ldots \ldots \ldots \ldots \ldots \ldots$ \\
Significance level & 0.048 \\
\hline
\end{tabular}

\begin{tabular}{|c|c|c|}
\hline \multicolumn{2}{|c|}{ Variable } & EG \\
\hline \multirow{4}{*}{$\begin{array}{l}\text { Arellano- } \\
\text { Bond test }\end{array}$} & \multirow{2}{*}{$A R(1)$} & $-1.70^{*}$ \\
\hline & & [0.090] \\
\hline & \multirow{2}{*}{$\operatorname{AR}(2)$} & -0.79 \\
\hline & & [0.432] \\
\hline \multirow{2}{*}{\multicolumn{2}{|c|}{ Sargan test }} & 2.59 \\
\hline & & [0.108] \\
\hline
\end{tabular}

Note: $* * *$ significant at $1 \%, * *$ - significant at $5 \%$, and $*$ significant at $10 \%$.

The result using the GMM is statistically significant. Also, both Sargan and Arellano-Bond tests are appropriate (Table 6). This result is thus eligible to be used. Accordingly, the estimation result (1) takes the following form:

$$
\begin{aligned}
& E G_{i t}=6.975+0.002 S M D_{i t}+ \\
& +0.005 D C_{i t}+0.019 C C_{i t}- \\
& -0.044 I N F_{i t}+\varepsilon_{i t} .
\end{aligned}
$$

This study reveals a positive influence (0.002) of SMD on EG in Asian EMDEs. This confirms the importance of SMD in improving efficient capital accumulation and allocation, and also allows investors to reduce risks and increase liquidity, thereby promoting EG. The finding is consistent with what was highlighted by Atje and Jovanovich (1993), Korajczyk (1996), Levine and Zervos (1998), Garrestsen et al. (2004), Nieuwerburgh et al. (2006), Colombage (2009), Enisan and Olufisayo (2009), Tsouma (2009), Cooray (2010), Estrada et al. (2010), Kolapo and Adaramola (2012), Ngare et al. (2014), Pradhan et al. (2014), and Setiawan et al. (2020). 
Table 6 also reports that EG is positively affected by DC (0.005) and CC (0.019). Further, INF has a negative influence on EG. This result is also in line with those of Ngare et al. (2014), Pradhan et al. (2014), and Botev et al. (2019). Accordingly, EG can increase if DC and CC are improved. This shows that credit and SMD play an important role in improving the ability to mobilize and allocate capital in the economy, which will boost EG. Not only that, the effective implementation of CC often brings many benefits to activities in the economy, which will also boost EG. However, if INF is too high, it can create many difficulties for the economy, which will hinder EG. Thus, besides the significant impact of SMD, EG is also substantially affected by economic growth through the banking sector, the effectiveness of the government's control of corruption, and inflation rate. These findings confirm that the impact of SMD on EG is suitable to classical economic growth models, especially the endogenous growth model. In addition, this study highlights the specific impact of SMD on EG in Asian EMDEs, greatly contributing to filling the current literature gap.

\section{CONCLUSION}

This study examines the impact of SMD on EG in Asian EMDEs over the period 2008-2019. It analyzes the complete data sample of eight Asian EMDEs, including China, Indonesia, India, Sri Lanka, Malaysia, the Philippines, Thailand, and Vietnam. To reach this objective, the GMM has been adopted. The result reports that SMD has a positive influence on EG in Asian EMDEs. This is consistent with classical economic growth theories, especially the endogenous growth theory. However, mainly investigating the explicit impact, the study resolves the existing limitation in the classical economic growth theories and previous studies by restricting financial development through the banking sector operation. In addition, this study finds a significant impact of DC, CC, and INF on EG. This suggests that the significant influence of DC, CC, and INF on EG is also highlighted. Generally, these findings are important for EMDEs in Asia. Based on them, EMDEs in Asia must develop effective policies to improve the stock market's scale, which contributes substantially to the development of EG. Moreover, EMDEs typically have low or middle income, so it is important to have a synchronous combination of various policies to stimulate SMD, improve governance effectiveness, implement effective macroeconomic policies, especially to proceed to promote comprehensive EG.

In general, this study is very successful in achieving its objective. More importantly, the study reports some interesting findings and fills the existing gap in the literature. Based on them, researchers can develop new proposals by expanding data in more countries or measuring SMD using different proxies.

\section{AUTHOR CONTRIBUTIONS}

Conceptualization: Toan Ngoc Bui.

Data curation: Thu-Trang Thi Doan.

Formal analysis: Toan Ngoc Bui, Thu-Trang Thi Doan.

Investigation: Thu-Trang Thi Doan.

Methodology: Toan Ngoc Bui.

Software: Toan Ngoc Bui.

Validation: Toan Ngoc Bui, Thu-Trang Thi Doan.

Visualization: Toan Ngoc Bui, Thu-Trang Thi Doan.

Writing-original draft: Thu-Trang Thi Doan.

Writing - review and editing: Toan Ngoc Bui, Thu-Trang Thi Doan.

\section{ACKNOWLEDGMENT}

This study was funded by the Industrial University of Ho Chi Minh City (IUH), Vietnam (grant number: 21/1TCNH01). 


\section{REFERENCES}

1. Arellano, M., \& Bond, S. (1991). Some tests of specification for panel data: Monte Carlo evidence and an application to employment fluctuations. Review of Economic Studies, 58(2), 277-297. https://doi. $\operatorname{org} / 10.2307 / 2297968$

2. Atje, R., \& Jovanovich, B. (1993). Stock markets and development. European Economic Review, 37(2-3), 632-640. https://doi. org/10.1016/0014-2921(93)90053D

3. Barro, R. J. (1991). Economic growth in a cross section of countries. Quarterly Journal of Economics, 106, 407-443. https:// doi.org/10.2307/2937943

4. Beck, T., \& Levine, R. (2004). Stock markets, banks, and growth: Panel evidence. Journal of Banking and Finance, 28(3), 423-442. https://doi.org/10.1016/S03784266(02)00408-9

5. Botev, J., Egert, B., \& Jawadi, F. (2019). The nonlinear relationship between economic growth and financial development: Evidence from developing, emerging and advanced economies. International Economics, 160, 3-13. https://doi. org/10.1016/j.inteco.2019.06.004

6. Cho, Y. J. (1986). Inefficiencies from financial liberalisation in the absence of well-functioning equity markets. Journal of Money, Credit, and Banking, 18(2), 191-199. https://doi.org/10.2307/1992202

7. Colombage, S. R. N. (2009). Financial markets and economic performances: Empirical evidence from five industrialized countries. Research in International Business and Finance, 23(3), 339-348. https://doi.org/10.1016/j.ribaf.2008.12.002

8. Cooray, A. (2010). Do stock markets lead to economic growth? Journal of Policy Modeling, 32, 448-460. https://doi.org/10.1016/j. jpolmod.2010.05.001

9. Demirguoc-Kunt, A., \& Levine, R. (1996). Stock market development and financial intermediaries: Stylized facts. World Bank Economic Review, 19(2), 291-322.
10. Enisan, A. A., \& Olufisayo, A. O. (2009). Stock market development and economic growth: Evidence from seven Sub-Saharan Africa. Journal of Economics and Business, 61(2), 162-171. https://doi.org/10.1016/j.jeconbus.2008.05.001

11. Estrada, G., Park, D., \& Ramayandi, A. (2010). Financial Development and Economic Growth in Developing Asia (ADB Working Economic Series, No. 233).

12. Garrestsen, H., Lensink, R., \& Sterken, E. (2004). Growth, financial development, societal norms and legal institutions. Journal of International Financial Markets, Institutions and Money, 14(2), 165-183. https://doi. org/10.1016/j.intfin.2003.06.002

13. Hoskisson, R. E., Eden, L., Lau, C. M., \& Wright, M. (2000) Strategy in Emerging Economies. Academy of Management Journal, 43(3), 249-267. https://doi. org/10.2307/1556394

14. Keynes, J. M. (1936). The General Theory of Employment, Interest and Money. London: Macmillan.

15. King, R. G., \& Levine, R. (1993a). Finance and growth: Schumpeter might be right. Quarterly Journal of Economics, 108(3), 717-738. https://doi.org/10.2307/2118406

16. King, R. G., \& Levine, R. (1993b). Finance, entrepreneurship and economic growth: Theory and evidence. Journal of Monetary Economics, 32(3), 513-542. https://doi.org/10.1016/03043932(93)90028-E

17. Kolapo, F. T., \& Adaramola, A. O. (2012). The impact of the Nigerian capital market on economic growth (1990-2010). International Journal of Developing Societies, 1(1), 11-19.

18. Korajczyk, R. A. (1996). A Measure of Stock Market Integration for Developed and Emerging Markets. World Bank Economic Review, 10(2), 267289. https://doi.org/10.1093/ wber/10.2.267
19. Levine, R., \& Zervos, S. (1998). Stock markets, banks and growth. American Economic Review, 88(3), 537-558.

20. Lucas, R. E. (1988). On the mechanics of economic development. Journal of Monetary Economics, 22(1), 3-42. https://doi. org/10.1016/0304-3932(88)90168-

21. Mankiw, N. G., Romer, D., \& Weil, D. (1992). A contribution to the empirics of economic growth. Quarterly Journal of Economics, 107(2), 407-437.

22. McKinnon, R. I. (1973). Money and capital in economic development. Washington, DC: The Brookings Institution.

23. Mody, A. (2004). What Is an Emerging Market? (IMF Working Paper WP/04/177).

24. Naceur, S. B., \& Ghazouani, S. (2007). Stock markets, banks, and economic growth: Empirical evidence from the MENA region. Research in International Business and Finance, 21(2), 297-315. https://doi.org/10.1016/j.ribaf.2006.05.002

25. Ngare, E., Nyamongo, E. M., \& Misati, R. N. (2014). Stock market development and economic growth in Africa. Journal of Economics and Business, 74, 24-39. http://dx.doi.org/10.1016/j.jeconbus.2014.03.002

26. Nguyen, M.-L. T., \& Bui, T. N. (2019). Stock market, real estate market, and economic growth: an ARDL approach. Investment Management and Financial Innovations, 16(4), 290-302. http://dx.doi.org/10.21511/ imfi.16(4).2019.25

27. Nieuwerburgh, S. V., Buelens, F., \& Cuyvers, L. (2006). Stock market development and economic growth in Belgium. Explorations in Economic History, 43(1), 13 38. https://doi.org/10.1016/j. eeh.2005.06.002

28. Olwenyand, T. O., \& Kimani, D. (2011). Stock market performance and economic growth empirical 
evidence from kenya using causality test approach. Advances in Management \& Applied Economics, 1(3), 153-196.

29. Pan, L., \& Mishra, V. (2017). Stock market development and economic growth: Empirical evidence from China. Economic Modelling, 68, 661-673. https:// doi.org/10.1016/j.econmod.2017.07.005

30. Pradhan, R. P., Arvin, M. B., Hall, J. H., \& Bahmani, S. (2014). Causa nexus between economic growth, banking sector development, stock market development, and other macroeconomic variables: The case of ASEAN countries. Review of Financial Economics, 23(4), 155-173. https://doi.org/10.1016/j. rfe.2014.07.002

31. Reinhart, C. M., \& Tokatlidis, I. (2003). Financial liberalization: The African experience. Journal of African Economies, 12(2), 53-88.

32. Ricardo, D. (1817). On the Principles of Political Economy and Taxation. London: John Murray.
33. Rousseau, P. L., \& Vuthipadadorn, D. (2005). Finance, investment and growth: time series evidence from 10 Asian economies. Journal of Macroeconomics, 27(1), 87-106. https://doi.org/10.1016/j.jmacro.2003.09.004

34. Rousseau, P. L., \& Wachtel, P. (2000). Banks, stock markets and China's great leap forward. Emerging Markets Review, 8(3), 206-217.

35. Schumpeter, J. A. (1911). The theory of economic development. Cambridge, MA: Harvard University Press.

36. Setiawan, B., Purnamasari, E., \& Ulum, M. B. (2020). Macroeconomic Indicators and Stock Market Development on Economic Growth: Empirical Evidence from ASEAN Countries Sriwijaya International Journal of Dynamic Economics and Business, 3(4), 271-282.

37. Shaw, E. S. (1973). Financial deepening in economic development. New York: Oxford University Press.
38. Smith, A. (1776). An Inquiry into the Nature and Causes of the Wealth of Nations (1st ed.). London: W. Strahan.

39. Solow, R. M. (1956). A Contribution to the Theory of Economic Growth. Quarterly Journal of Economics, 70(1), 65-94. https://doi.org/10.2307/1884513

40. Swan, T. W. (1956). Economic Growth and Capital Accumulation. Economic Record, 32(2), 324-361. https://doi. org/10.1111/j.1475-4932.1956. tb00434.x

41. Tsouma, E. (2009). Stock returns and economic activity in nature and emerging markets. Quarterly Review of Economics and Finance, 49(2), 668-685. https://doi. org/10.1016/j.qref.2008.02.002

42. Xu, Z. (2000). Financial development, investment, and economic growth. Economic Inquiry, 38(2), 331-344. https:// doi.org/10.1111/j.1465-7295.2000. tb00021.x 